Research Article

\title{
Safety Assessment of Methanol Extract of Melastoma malabathricum L. Leaves following the Subacute and Subchronic Oral Consumptions in Rats and Its Cytotoxic Effect against the HT29 Cancer Cell Line
}

\author{
N. E. Kamsani, ${ }^{1}$ Z. A. Zakaria ${ }^{\mathbb{D}},{ }^{1}$ N. L. Md Nasir, ${ }^{1}$ N. Mohtarrudin, ${ }^{2}$ \\ and N. B. Mohamad Alitheen ${ }^{3}$ \\ ${ }^{1}$ Department of Biomedical Science, Faculty of Medicine and Health Sciences, Universiti Putra Malaysia, 43400 UPM Serdang, \\ Selangor Darul Ehsan, Malaysia \\ ${ }^{2}$ Department of Pathology, Faculty of Medicine and Health Sciences, Universiti Putra Malaysia, 43400 UPM Serdang, \\ Selangor Darul Ehsan, Malaysia \\ ${ }^{3}$ Department of Cell and Molecular Biology, Faculty of Biotechnology and Biomolecular Sciences, Universiti Putra Malaysia, \\ 43400 UPM Serdang, Selangor Darul Ehsan, Malaysia
}

Correspondence should be addressed to Z. A. Zakaria; drzazakaria@gmail.com

Received 15 July 2019; Accepted 25 October 2019; Published 26 November 2019

Academic Editor: Raffaele Capasso

Copyright (C) 2019 N. E. Kamsani et al. This is an open access article distributed under the Creative Commons Attribution License, which permits unrestricted use, distribution, and reproduction in any medium, provided the original work is properly cited.

\begin{abstract}
Methanol extract of Melastoma malabathricum (MEMM) has been traditionally used by the Malay to treat various ailments. In an attempt to develop the plant as an herbal product, MEMM was subjected to the subacute and subchronic toxicity and cytotoxicity studies. On the one hand, the subacute study was performed on three groups of male and three groups of female rats $(n=6)$, which were orally administered with $8 \%$ Tween 80 (vehicle control group) or MEMM (500 and $1000 \mathrm{mg} / \mathrm{kg}$ ) daily for 28 days, respectively. On the other hand, the subchronic study was performed on four groups of rats $(n=6)$, which were orally administered with $8 \%$ Tween 80 (vehicle control group) or MEMM (50,250, and $500 \mathrm{mg} / \mathrm{kg}$ ) daily for 90 days, respectively. In the in vitro study, the cytotoxic effect of MEMM against the HT29 colon cancer cell line was assessed using the MTT assay. MEMM was also subjected to the UHPLC-ESI-HRMS analysis. The results demonstrated that MEMM administration did not cause any mortality, irregularity of behaviour, modification in body weight, as well as food and water intake following the subacute and subchronic oral treatment. There were no significant differences observed in haematological parameters between treatment and control groups in both studies, respectively. The in vitro study demonstrated that MEMM exerts a cytotoxic effect against the HT29 colon cancer cell line when observed under the inverted and phase-contrast microscope and confirmed by the acridine orange/propidium iodide (AOPI) staining. The UHPLC-ESI-HRMS analysis of MEMM demonstrated the occurrence of several compounds including quercetin, p-coumaric acid, procyanidin A, and epigallocatechin. In conclusion, M. malabathricum leaves are safe for oral consumption either at the subacute or subchronic levels and possess cytotoxic action against the HT29 colon cancer cells possibly due to the synergistic action of several flavonoid-based compounds.
\end{abstract}

\section{Introduction}

Melastoma malabathricum (family Melastomaceae) has been applied in various folklore medicines to heal diverse forms of maladies [1-3]. Scientifically, various reports on $M$. malabathricum have been published and extensively reviewed by Joffry et al. [4]. With regard to the methanol extract of M. malabathricum leaves (MEMM) toxic effect, only the acute toxicity study has been carried out on MEMM using the OECD Guideline No. 423 [5]. Interestingly, MEMM was reported to show no toxic effect at the dose of $5000 \mathrm{mg} / \mathrm{kg}$ when given orally [5]. Meanwhile, with regard to the cytotoxic effect of $M$. malabathricum, MEMM has been reported to show cytotoxic activities against several murine 
(i.e., 3LL (Lewis lung carcinoma cells) and L1210 (leukemic cells)) and human (i.e., K562 (chronic myeloid leukaemia), DU145 (prostatic adenocarcinoma), MCF-7 (mammal carcinoma), and U251 (glioblastoma)) cancer lines [6], but not Vero cell line (African green monkey, Cercopitheus aethiops kidney cells) and mouse fibroblast cell line (L929) [7], respectively.

Along the course of developing a potent natural-based product, toxicity or the adverse effects of the plant extract on living organisms has been one of the major issues. Although M. malabathricum has been given the herbal status in Malaysia and several scientific studies have confirmed its medicinal values, further studies need to be carried out to establish its toxicity profile. In addition, despite the cytotoxic reports of MEMM described above, no attempt has been made to investigate the cytotoxic effect of MEMM against the HT29 colon cancer cell line. Taking into account that (i) MEMM was reported to be safe at $5000 \mathrm{mg} / \mathrm{kg}$ when assessed using the acute toxicity model MEMM and (ii) MEMM was cytotoxic only against 3LL, L1210, and U251 cancer cell lines with no report against HT29 colon cancer cell line, the present study was designed to determine the toxic effect of MEMM following its subacute and subchronic oral exposure for 28 or 90 days, respectively, and to evaluate the cytotoxic activity of MEMM against the HT29 cancer cell line.

\section{Materials and Methods}

2.1. Sample Collection and Preparation of Crude Extract. The leaves of $M$. malabathricum were collected between June and July 2013 from its natural habitat around Serdang, Selangor, Malaysia, based on the voucher specimen (SK 2199/13) deposited earlier in the herbarium of Institute of Bioscience, Universiti Putra Malaysia.

The crude extract of $M$. malabathricum was prepared as stated by Mamat et al. [8]. In brief, the dried leaves in powder form $(200 \mathrm{~g}$ ) were soaked in $4000 \mathrm{~mL}$ methanol for $72 \mathrm{~h}$ and this procedure was performed three times to obtain the supernatant. The supernatant was then evaporated at $40^{\circ} \mathrm{C}$ under reduced pressure to acquire the crude methanol extract (MEMM). The extract was left in the oven at $40^{\circ} \mathrm{C}$ to allow the solvent residue to dry and occasionally weighed until a constant weight was obtained.

\subsection{In Vivo Study}

2.2.1. Experimental Animals. Sprague-Dawley rats (4 weeks of age; weighed between 120 and $150 \mathrm{~g}$ ) were purchased from the Faculty of Veterinary Medicine, UPM, and acclimatized in the animal house of the Faculty of Medicine and Health Sciences (FMHS), UPM, under control temperature $\left(22 \pm 2^{\circ} \mathrm{C}\right), 70-80 \%$ humidity with $12 \mathrm{~h}$ light/dark cycle. The rats were allowed access to basal diet and water ad libitum and monitored according to the guidelines accepted by the Institutional Animal Care and Use Committee (IACUC), FMHS, UPM [8]. Ethics approval for animal care and use was approved by the IACUC (IACUC no: UPM/IACUC/ AUP-R007/2014).
2.2.2. Preparation and Administration of Different Dosages of MEMM. MEMM was dissolved in $8 \%$ Tween 80 to the required dose using a sonicator at $40^{\circ} \mathrm{C}$ for $5-10 \mathrm{~min}$. Animals were administered orally with the freshly prepared extract or vehicle daily according to their body weight [9].

2.2.3. Subacute Toxicity Study. Eighteen (18) male and eighteen (18) female rats were each randomly allocated into three groups $(n=6)$ and treated via oral gavage daily for 28 days with $8 \%$ Tween $80,500 \mathrm{mg} / \mathrm{kg}$ MEMM, or $1000 \mathrm{mg} /$ kg MEMM. Body weight was recorded weekly and on the 28th day prior to the termination of the experiment. The subacute toxicity study was performed according to the OECD Test Guideline 407 [10].

2.2.4. Subchronic Toxicity Study. Twenty-four male rats were randomly allocated into four groups $(n=6)$ and treated via oral gavage daily for 90 days with $8 \%$ Tween $80,50 \mathrm{mg} / \mathrm{kg}$ MEMM, $250 \mathrm{mg} / \mathrm{kg}$ MEMM, or $500 \mathrm{mg} / \mathrm{kg}$ MEMM. Body weight was recorded weekly and on the 90th day prior to the termination of the experiment. The subchronic toxicity study was performed according to the OECD Test Guideline $408[11]$.

2.2.5. Sample Collection. Depending on the model of toxicity studies, the rats were weighed and then anesthetized with ketamine $(100 \mathrm{mg} / \mathrm{kg}$; intramuscular (i.m.)) and xylazine $\left(16 \mathrm{mg} / \mathrm{kg}\right.$; i.m.) on the respective $28^{\text {th }}$ or $90^{\text {th }}$ day prior to the collection of blood and tissues [12]. The whole blood was obtained through cardiac puncture and kept in the labeled plain and EDTA-containing vacutainer tubes (BD Plymouth, UK). Blood in the EDTA vacutainers was kept at $4^{\circ} \mathrm{C}$, while blood in the plain (non-EDTA-containing) vacutainers was subjected to the centrifugation procedure (at $1500 \mathrm{~g}$ for $3 \mathrm{~min}$ ) to obtain the serum, which was then kept at $-20^{\circ} \mathrm{C}$. Following the blood collection, the rats were sacrificed by cervical dislocation and then dissected to collect the important organs, namely, liver, spleen, kidneys, stomach, heart, and lungs. Each organ was rinsed with normal saline and their weights were then recorded before being fixed in $10 \%$ buffered formalin for further histopathological study.

2.2.6. Haematological and Biochemical Analysis. The toxic outcome of subacute or subchronic oral administration of MEMM was evaluated using the samples collected as described above. The whole blood in the EDTA-containing vacutainers was processed within $24 \mathrm{~h}$ and then subjected to the haematological analysis using the automated analyser (Coulter STKS, Beckman) to yield information on several haematological parameters (i.e., total red blood cell (RBC) count, haemoglobin $(\mathrm{Hb})$, mean corpuscular haemoglobin concentration (MCHC), mean corpuscular volume (MCV), packed cell volume (PCV), total white blood cell (WBC) count, neutrophils, monocytes, lymphocytes, and eosinophils).

The serum, which was earlier kept at $-20^{\circ} \mathrm{C}$, was thawed at $25^{\circ} \mathrm{C}$ and treated within two days following the blood 
collection. Biochemical analysis was performed using an automated biochemical analyser (Hitachi 902, Japan) for several biochemical parameters (i.e., alanine aminotransferase (ALT), alkaline phosphatase (ALP), aspartate aminotransferase (AST), creatinine (Crea), urea, and total bilirubin (TBil)). The control group mean values were used as the baseline for comparison with treatment groups.

2.2.7. Histopathological Study. The whole rat organs, collected following the subacute and subchronic studies and kept in $10 \%$ buffered formalin, were sectioned and prepared as previously described [13]. Sections were stained with Haematoxylin and Eosin $(\mathrm{H} \& \mathrm{E})$ and then microscopically examined for pathological changes at 10x, 20x, and $40 \mathrm{x}$ magnifications.

\subsection{In Vitro Study}

2.3.1. Cell Line Cultivation. Normal mouse fibroblast (3T3) and human colon cancer (HT29) cell lines were procured from the American Type Culture Collection (ATCC). Cells were grown and maintained in Roswell Park Memorial Institute-1640 (RPMI) media added with 10\% fetal bovine serum (FBS) and 1\% penicillin-streptomycin (Pen-Strep). Cells were cultured at humidified atmosphere 5\% carbon dioxide $\left(\mathrm{CO}_{2}\right)$ at $37^{\circ} \mathrm{C}$ in an incubator. Trypsin-EDTA was then used to detach the confluent cells at $80 \%$ confluency. The cells were then stained with trypan blue before the cell number, and viability was determined using a haemocytometer [14].

2.3.2. Cell Proliferation Assay. $1 \times 10^{5}$ cells (3T3 or HT29) were seeded in a 96-well plate. Upon $24 \mathrm{~h}$ of incubation at $37^{\circ} \mathrm{C}$ with $5 \% \mathrm{CO}_{2}$ atmosphere, the media were discarded and replaced with fresh complete media (10\% FBS and 1\% Pen-Strep) containing MEMM dried extract. The dried extract was diluted in dimethyl sulfoxide (DMSO) to prepare the starting concentration of $200 \mu \mathrm{g} / \mathrm{mL}$, which was then serially diluted to the lowest concentration of $0.156 \mu \mathrm{g} / \mathrm{mL}$. Negative control was not treated with MEMM. After $72 \mathrm{~h}$ of incubation, $20 \mu \mathrm{L}$ of 3-(4,5-dimethylthiazol-2-yl)-2,5diphenyltetrazolium bromide (MTT) in phosphate buffer saline (PBS) was added to each well. The plate was incubated again for 3 to $4 \mathrm{~h}$. Next, the medium from each well was discarded, and $100 \mu \mathrm{L}$ of DMSO was added, mixed thoroughly for $5 \mathrm{~min}$ to form purple formazan. The plate was then read using the ELISA reader. A graph of cell viability against concentration was plotted. Inhibitory concentration $\left(\mathrm{IC}_{50}\right)$ can be defined as the concentration of MEMM that caused approximately $50 \%$ of cell death [14].

2.3.3. Inverted Microscope Study. HT29 cells were seeded at $1 \times 10^{5}$ cells in a 6 -well plate and incubated overnight at $37^{\circ} \mathrm{C}$ with $5 \% \mathrm{CO}_{2}$ atmosphere. After incubation, the media was discarded and substituted with fresh complete media containing MEMM. After $72 \mathrm{~h}$ of incubation, morphological changes of the cells were examined by using an inverted microscope at 10x, 20x, and 40x actual magnification [15].

2.3.4. Phase-Contrast Examination. HT29 cells were seeded in a 6-well plate with completed media and incubated at $37^{\circ} \mathrm{C}$ with $5 \% \mathrm{CO}_{2}$ atmosphere. The media was discarded and substituted with fresh complete media containing MEMM on the next day. After $72 \mathrm{~h}$ of incubation, the cellular structure in the bright field was examined by phase contrast using a light microscope at 10x, 20x, and 40x actual magnification [15].

2.3.5. Acridine Orange/Propidium Iodide (AOPI) Staining. Approximately, $1 \times 10^{5}$ of HT29 cells were seeded in a 6-well plate and incubated for $24 \mathrm{~h}$ at $37^{\circ} \mathrm{C}$ with $5 \% \mathrm{CO}_{2}$ atmosphere. The media was discarded and substituted with fresh complete media containing MEMM and incubated again for $72 \mathrm{~h}$. After incubation, the cells were trypsinized with trypsin-EDTA and washed with PBS. $10 \mu \mathrm{L}$ of cells from each well were put on a glass slide and mixed with $10 \mu \mathrm{l}$ of acridine orange $(\mathrm{AO})(50 \mu \mathrm{g} / \mathrm{mL})$ and $10 \mu \mathrm{l}$ of propidium iodide (PI) $(50 \mu \mathrm{g} / \mathrm{mL})$. The nucleus of viable and dead cells was viewed under a fluorescence microscope for qualitative and quantitative approaches [16].

2.3.6. High-Resolution UPLC-ESI-HRMS Analysis of MEMM. Chromatography separation of MEMM was performed on the Dionex Ultimate 3000 RS UHPLC system comprising a UHPLC pump, an auto sample operating at $4^{\circ} \mathrm{C}$, and Exactive Orbitrap mass spectrometer with a heated electrospray ionization probe operating in the negative ionization mode (Thermo Fisher Scientific, San Jose, CA). In brief, reverse separations were carried out using the RP Max column $(250 \times 4.6 \mathrm{~mm}$, particle size $4.0 \mu \mathrm{m}$; Synergi) maintained at $40^{\circ} \mathrm{C}$ and eluted at a flow rate of $0.3 \mathrm{~mL} / \mathrm{min}$ with $25 \mathrm{~min}$ gradient of $10-50 \%$ of $0.1 \%$ acidic acetonitrile in $0.1 \%$ aqueous formic acid. The conditions were set as follows: sheath gas at 15 (arbitrary units), aux at 20 and sweep gas at 5 (arbitrary units), spray voltage at $3.0 \mathrm{kV}$, capillary temperature at $350^{\circ} \mathrm{C}$, and s-lens $\mathrm{RF}$ level at $55 \mathrm{~V}$. The mass range was from 100 to $1500 \mathrm{amu}$ with a resolution of 17,000 , FTMS AGC target at $2 e 5$, FTMS/MS AGC target at $1 e 5$, isolation width of $1.5 \mathrm{amu}$, maximum ion injection time of $500 \mathrm{~ms}$, and the normalization collision energy at $35 \%$.

2.3.7. Statistical Analyses. The results obtained were statistically analysed (Graph Pad Prism version 5.02) using the oneway analysis of variance (ANOVA) followed by the Dunnett post hoc test. Data were expressed as means \pm standard error mean (SEM) with $P<0.05$ as the limit of significance.

\section{Results}

3.1. In Vivo Subacute and Subchronic Toxicity Studies. In the present study, the subacute and subchronic toxicities of MEMM were assessed in rats after the daily oral 
consumption of MEMM for 28 and 90 days, respectively. The dosages used for the subacute toxicity study was 500 and $1000 \mathrm{mg} / \mathrm{kg} /$ day, while for the subchronic toxicity study, the dosages used were 50,250 , and $500 \mathrm{mg} / \mathrm{kg} /$ day.

\subsection{Findings on the Physical Signs, Body Weight, and Food and} Water Consumption. All tested groups of rats were found to be equally healthy throughout both toxicity studies, wherein no signs of changes in behaviour were observed. Interestingly, the administration of MEMM for 28 or 90 days also did not cause any clinical signs of toxicity or mortality in rats. Although weight gain was detected in all rats administered with MEMM throughout the experimental periods, a comparison between the MEMM-treated groups against the control group showed insignificant $(P>0.05)$ changes in the weight gain at their respective interval (data not shown). In addition, insignificant $(P>0.05)$ changes in food and water consumption were seen when the MEMM-treated rats were compared to the normal control rats (data not shown).

3.3. Relative Organ Weight and Macroscopic Findings. The relative organ weight of Sprague-Dawley rats following the subacute and subchronic toxicity studies is shown in Tables 1 and 2, respectively. There were insignificant $(P>0.05)$ changes in the liver weight/body weight ratio for all the collected organs, namely, liver, kidneys, heart, spleen, lungs, or stomach of MEMM-treated rats in comparison to the normal control rats. Further macroscopic assessments of the harvested organs showed that the MEMM pretreatment did not change the colour or induce hypertrophy of those organs when compared against the respective organ of the normal control group (data not shown).

3.4. Haematological and Biochemical Findings. To support the above observations, haematological and biochemical analyses were also performed on the blood, liver, and urine collected from the rats. Analysis of the haematological parameters of MEMM-treated groups also showed insignificant $(P>0.05)$ difference when compared to the normal control group for both the subacute (Table 3) and subchronic (Table 4) studies. A normal haematological profile was recorded in MEMM-treated groups in comparison to the normal control group for both toxicity studies.

On the contrary, biochemical analysis of the hepatic and renal function parameters demonstrated that MEMM treatment caused insignificant $(P>0.05)$ changes in all parameters evaluated in both the toxicity studies (Table 5), except for the hepatic function parameters of the subchronic toxicity study, whereby a significant $(P<0.05)$ increase in the level of ALP was observed only in the groups pretreated with 250 and $500 \mathrm{mg} / \mathrm{kg}$ MEMM in comparison to the normal control group (Table 6).

3.5. Histopathology and Microscopic Findings. Further support on the above observations was obtained microscopically wherein all harvested organs pretreated with MEMM in the subacute and subchronic toxicity studies demonstrated no signs of toxicity when compared to the respective normal control group. This assumption is made based on the indication that there is no change in the architecture of cells when observed under the light microscope at numerous magnification powers. No pathological signs were documented in the histological analysis of the vital organs of the control group. Thus, not all figures of the collected organs were presented in the manuscript. Only micrographs of selected organs (i.e., liver and kidney) harvested from rats following the subchronic toxicity study were shown (Figures 1(a) and 1(b), respectively).

\subsection{In Vitro Cytotoxic Study}

3.6.1. Cytotoxicity Effect against HT29 Cells. The cytotoxic potential of MEMM, at the highest concentration of $200 \mu \mathrm{g} /$ $\mathrm{ml}$, was evaluated against HT29 cells using the MTT assay. The extract was serially diluted to produce a concentration range of $0.156-200 \mu \mathrm{g} / \mathrm{ml}$ and then subjected to the MTT assay.

3.6.2. Antiproliferative Effect against HT29 Cell Line. Treatment with MEMM had promoted antiproliferation of the HT29 cells. After $72 \mathrm{~h}$, cell proliferation was decreased to $50 \%$ compared to the untreated HT29 cells. The IC $^{50}$ obtained for MEMM was approximately $100 \mu \mathrm{g} / \mathrm{mL}$.

3.6.3. Inverted Microscope Observation. After incubation with MEMM (50, 100, and $150 \mu \mathrm{g} / \mathrm{mL})$, morphological modifications in HT29 cells were seen at 100 and $150 \mu \mathrm{g} / \mathrm{mL}$ and compared to the control untreated cells (Figure 2). Untreated HT29 cells were observed with normal morphology while those treated with 100 and $150 \mu \mathrm{g} / \mathrm{mL}$ MEMM exerted retraction and rounding of cells with some sensitive cells detached from the surface.

3.6.4. Phase-Contrast Examination. After incubation with MEMM (50, 100, and $150 \mu \mathrm{g} / \mathrm{mL})$, morphological modifications of HT29 cells were observed at 100 and $150 \mu \mathrm{g} / \mathrm{mL}$ in comparison to the control untreated cells (Figure 2). Untreated cells were seen to possess normal morphology. Instead, exposure of HT29 cells to 100 and $150 \mu \mathrm{g} / \mathrm{mL}$ MEMM was found to lead to retraction and rounding of cells. In addition, some sensitive cells were found to detach from the surface.

3.6.5. Acridine Orange/Propidium Iodide Staining. Viable HT29 cells were seen with intact DNA, round-shaped nucleus, and green nuclei, whereas the early apoptotic cells were indicated by green, fragmented nucleus. On the contrary, the cells that were undergoing the late apoptotic or necrotic phase were stained orange and red. It is clear from Figure 2 that an increase in the concentration of MEMM (50, 100 , and $150 \mu \mathrm{g} / \mathrm{mL}$ ) leads to a decrease in the number of viable HT29 cancer cells. Moreover, apoptotic cells also exhibited several other characteristics such as plasma membrane blebbing, nuclear shrinking, and fragmentation.

In addition, the percentage of viable, apoptotic, and necrotic cells was also quantified and presented in Table 7. 
TABLE 1: Relative organ weight of Sprague-Dawley rats following the 28-day oral pretreatment with vehicle (Tween 80 ) or MEMM in the subacute toxicity study.

\begin{tabular}{|c|c|c|c|c|c|c|}
\hline \multirow{4}{*}{ Organs } & \multicolumn{3}{|c|}{ Male } & \multicolumn{3}{|c|}{ Female } \\
\hline & \multirow{3}{*}{$\begin{array}{c}\text { Control } \\
\text { Tween } 80 \\
-\end{array}$} & \multirow{2}{*}{\multicolumn{2}{|c|}{$\begin{array}{c}\text { Treatment } \\
\text { MEMM (mg/kg) }\end{array}$}} & \multirow{3}{*}{$\begin{array}{c}\text { Control } \\
\text { Tween } 80 \\
-\end{array}$} & \multirow{2}{*}{\multicolumn{2}{|c|}{$\begin{array}{c}\text { Treatment } \\
\text { MEMM (mg/kg) }\end{array}$}} \\
\hline & & & & & & \\
\hline & & 500 & 1000 & & 500 & 1000 \\
\hline Spleen & $0.62 \pm 0.09$ & $0.53 \pm 0.13$ & $0.61 \pm 0.17$ & $0.71 \pm 0.03$ & $0.63 \pm 0.09$ & $0.39 \pm 0.03$ \\
\hline Heart & $0.47 \pm 0.04$ & $0.42 \pm 0.03$ & $0.46 \pm 0.03$ & $0.42 \pm 0.05$ & $0.39 \pm 0.03$ & $0.42 \pm 0.03$ \\
\hline Liver & $5.35 \pm 0.19$ & $5.14 \pm 0.44$ & $5.58 \pm 0.30$ & $4.97 \pm 0.44$ & $5.10 \pm 0.27$ & $4.69 \pm 0.28$ \\
\hline Kidney & $1.46 \pm 0.06$ & $1.41 \pm 0.07$ & $1.55 \pm 0.05$ & $1.29 \pm 0.12$ & $1.20 \pm 0.11$ & $1.08 \pm 0.02$ \\
\hline Stomach & $0.95 \pm 0.14$ & $0.78 \pm 0.07$ & $0.80 \pm 0.06$ & $0.87 \pm 0.13$ & $0.71 \pm 0.07$ & $0.90 \pm 0.04$ \\
\hline Lung & $0.85 \pm 0.04$ & $0.88 \pm 0.14$ & $0.99 \pm 0.08$ & $0.87 \pm 0.04$ & $1.20 \pm 0.27$ & $0.77 \pm 0.04$ \\
\hline
\end{tabular}

Values are expressed as means \pm SEM. Groups $(n=6)$ : control (treated with Tween 80 ); treatments (treated with $500 \mathrm{mg} / \mathrm{kg}$ MEMM and $1000 \mathrm{mg} / \mathrm{kg}$ MEMM).

TABLE 2: Relative organ weight of Sprague-Dawley rats following the 90-day oral pretreatment with vehicle (Tween 80 ) or MEMM in the subchronic toxicity study.

\begin{tabular}{|c|c|c|c|c|}
\hline \multirow{4}{*}{ Organs } & \multicolumn{4}{|c|}{ Male } \\
\hline & \multirow{3}{*}{$\begin{array}{c}\text { Control } \\
\text { Tween } 80 \\
-\end{array}$} & \multirow{2}{*}{\multicolumn{3}{|c|}{$\begin{array}{c}\text { Treatment } \\
\text { MEMM (mg/kg) }\end{array}$}} \\
\hline & & & & \\
\hline & & 50 & 250 & 500 \\
\hline Spleen & $0.21 \pm 0.04$ & $0.17 \pm 0.01$ & $0.20 \pm 0.02$ & $0.16 \pm 0.01$ \\
\hline Liver & $2.76 \pm 0.35$ & $3.76 \pm 0.07$ & $2.93 \pm 0.25$ & $2.71 \pm 0.12$ \\
\hline Heart & $0.35 \pm 0.03$ & $0.33 \pm 0.01$ & $0.34 \pm 0.02$ & $0.29 \pm 0.02$ \\
\hline Kidney & $0.74 \pm 0.06$ & $0.64 \pm 0.02$ & $0.72 \pm 0.03$ & $0.61 \pm 0.01$ \\
\hline Lung & $0.78 \pm 0.07$ & $0.71 \pm 0.04$ & $0.95 \pm 0.13$ & $0.90 \pm 0.11$ \\
\hline Colon & $0.84 \pm 0.13$ & $0.77 \pm 0.07$ & $0.81 \pm 0.07$ & $0.70 \pm 0.03$ \\
\hline
\end{tabular}

Values are expressed as means \pm SEM. Groups $(n=6)$ : control (treated with Tween 80 ); treatments (treated with $50 \mathrm{mg} / \mathrm{kg}$ MEMM, $250 \mathrm{mg} / \mathrm{kg}$ MEMM, and $1000 \mathrm{mg} / \mathrm{kg}$ MEMM).

TABLe 3: Haematological profiles of Sprague-Dawley rats following the 28-day oral pretreatment with vehicle (Tween 80) or MEMM in the subacute toxicity study.

\begin{tabular}{|c|c|c|c|c|c|c|}
\hline \multirow{4}{*}{ Haematological parameters } & \multicolumn{3}{|c|}{ Male } & \multicolumn{3}{|c|}{ Female } \\
\hline & \multirow{3}{*}{$\begin{array}{c}\text { Control } \\
\text { Tween } 80 \\
-\end{array}$} & \multirow{2}{*}{\multicolumn{2}{|c|}{$\begin{array}{c}\text { Treatment } \\
\text { MEMM (mg/kg) }\end{array}$}} & \multirow{3}{*}{$\begin{array}{c}\text { Control } \\
\text { Tween } 80 \\
-\end{array}$} & \multirow{2}{*}{\multicolumn{2}{|c|}{$\begin{array}{c}\text { Treatment } \\
\text { MEMM (mg/kg) }\end{array}$}} \\
\hline & & & & & & \\
\hline & & 500 & 1000 & & 500 & 1000 \\
\hline $\mathrm{RBC}\left(\times 10^{12} / \mathrm{L}\right)$ & $8.36 \pm 0.22$ & $8.42 \pm 0.31$ & $8.66 \pm 0.77$ & $7.73 \pm 0.93$ & $7.89 \pm 0.83$ & $9.46 \pm 0.47$ \\
\hline WBC $\left(\times 10^{9} / \mathrm{L}\right)$ & $3.74 \pm 0.41$ & $3.02 \pm 0.81$ & $4.86 \pm 0.93$ & $4.83 \pm 0.51$ & $6.30 \pm 1.62$ & $3.62 \pm 0.70$ \\
\hline $\mathrm{Hb}(\mathrm{g} / \mathrm{L})$ & $138.40 \pm 3.06$ & $129.40 \pm 5.04$ & $122.20 \pm 8.41$ & $125.71 \pm 11.44$ & $108.40 \pm 13.11$ & $134.00 \pm 12.36$ \\
\hline $\mathrm{PCV}(\mathrm{L} / \mathrm{L})$ & $0.36 \pm 0.01$ & $0.33 \pm 0.01$ & $0.31 \pm 0.02$ & $0.41 \pm 0.10$ & $0.27 \pm 0.03$ & $0.32 \pm 0.02$ \\
\hline $\mathrm{MCV}(\mathrm{fL})$ & $43.40 \pm 2.51$ & $39.00 \pm 1.05$ & $35.80 \pm 2.65$ & $37.21 \pm 0.62$ & $34.60 \pm 0.87$ & $34.20 \pm 1.99$ \\
\hline $\mathrm{MCHC}(\mathrm{g} / \mathrm{L})$ & $382.80 \pm 7.81$ & $395.20 \pm 6.49$ & $401.20 \pm 10.85$ & $388.67 \pm 22.21$ & $393.80 \pm 18.00$ & $413.20 \pm 16.46$ \\
\hline Neutrophils $\left(\times 10^{9} / \mathrm{L}\right)$ & $10.80 \pm 1.20$ & $10.60 \pm 1.94$ & $9.50 \pm 2.5$ & $12.61 \pm 1.27$ & $14.20 \pm 2.60$ & $16.00 \pm 2.52$ \\
\hline Lymphocytes $\left(\times 10^{9} / \mathrm{L}\right)$ & $71.60 \pm 1.60$ & $79.20 \pm 3.40^{*}$ & $81.25 \pm 3.84$ & $68.77 \pm 5.34$ & $57.00 \pm 4.67$ & $73.33 \pm 2.73$ \\
\hline Monocytes $\left(\times 10^{9} / \mathrm{L}\right)$ & $5.00 \pm 0.55$ & $6.40 \pm 1.44$ & $5.08 \pm 0.41$ & $5.41 \pm 0.52$ & $6.40 \pm 1.03$ & $4.67 \pm 0.33$ \\
\hline Eosinophils $\left(\times 10^{9} / \mathrm{L}\right)$ & $3.40 \pm 0.75$ & $2.40 \pm 0.24$ & $2.75 \pm 0.48$ & $3.22 \pm 0.43$ & $4.20 \pm 1.72$ & $4.00 \pm 1.16$ \\
\hline
\end{tabular}

Values are expressed as means \pm SEM. Groups $(n=6$ ): control (treated with Tween 80 ); treatments (treated with $500 \mathrm{mg} / \mathrm{kg} \mathrm{MEMM}$ and $1000 \mathrm{mg} / \mathrm{kg}$ MEMM).

AO stained early apoptotic cells green, whereas PI stained late apoptotic and necrotic cells. The percentage of viable HT29 cells was decreased once incubated with MEMM. Apoptotic and necrotic cells, however, were increased after $72 \mathrm{~h}$.

3.6.6. UHPLC-ESI-HRMS Profile of MEMM. MEMM was subjected to the reversed-phase UHPLC-ESI-HRMS analysis to determine its phytochemical constituents using a gradient mobile phase comprising $0.1 \%$ aqueous formic acid and $0.1 \%$ acetonitrile. This condition will allow for a comprehensive elution of plant analytes within $35 \mathrm{~min}$. Thoroughness in identification was due in part to a higher sensitivity of the UHPLC-MS and processing Xcalibur software. Assignments of metabolites were carried out by comparing the retention time, MS data (accurate mass, isotopic distribution, and 
TABLE 4: Haematological profiles of Sprague-Dawley rats following the 90-day oral pretreatment with vehicle (Tween 80) or MEMM in the subchronic toxicity study.

\begin{tabular}{|c|c|c|c|c|}
\hline \multirow{4}{*}{ Haematological parameters } & \multicolumn{4}{|c|}{ Male } \\
\hline & \multirow{3}{*}{$\begin{array}{c}\text { Control } \\
\text { Tween } 80 \\
-\end{array}$} & \multirow{2}{*}{\multicolumn{3}{|c|}{$\begin{array}{c}\text { Treatment } \\
\text { MEMM (mg/kg) }\end{array}$}} \\
\hline & & & & \\
\hline & & 50 & 500 & 1000 \\
\hline $\mathrm{RBC}\left(\times 10^{12} / \mathrm{L}\right)$ & $8.15 \pm 0.32$ & $8.25 \pm 0.17$ & $6.98 \pm 0.91$ & $6.61 \pm 0.73$ \\
\hline $\mathrm{WBC}\left(\times 10^{9} / \mathrm{L}\right)$ & $153.30 \pm 9.42$ & $155.80 \pm 2.50$ & $133.31 \pm 15.80$ & $132.80 \pm 14.73$ \\
\hline $\mathrm{Hb}(\mathrm{g} / \mathrm{L})$ & $0.40 \pm 0.02$ & $0.41 \pm 0.010$ & $0.34 \pm 0.04$ & $0.35 \pm 0.04$ \\
\hline $\mathrm{PCV}(\mathrm{L} / \mathrm{L})$ & $49.25 \pm 0.75$ & $49.75 \pm 1.32$ & $49.25 \pm 1.60$ & $52.25 \pm 0.63$ \\
\hline $\mathrm{MCV}(\mathrm{fL})$ & $383.00 \pm 11.71$ & $380.80 \pm 10.04$ & $393.00 \pm 6.55$ & $385.30 \pm 6.30$ \\
\hline $\mathrm{MCHC}(\mathrm{g} / \mathrm{L})$ & $8.44 \pm 1.86$ & $7.85 \pm 0.69$ & $11.08 \pm 3.12$ & $8.30 \pm 1.87$ \\
\hline Neutrophils $\left(\times 10^{9} / \mathrm{L}\right)$ & $2.51 \pm 0.50$ & $3.48 \pm 0.58$ & $3.03 \pm 0.92$ & $3.53 \pm 0.83$ \\
\hline Lymphocytes $\left(\times 10^{9} / \mathrm{L}\right)$ & $4.89 \pm 1.16$ & $3.60 \pm 0.20$ & $6.42 \pm 1.24$ & $3.92 \pm 0.93$ \\
\hline Monocytes $\left(\times 10^{9} / \mathrm{L}\right)$ & $0.55 \pm 0.14$ & $0.46 \pm 0.08$ & $0.61 \pm 0.14$ & $0.53 \pm 0.17$ \\
\hline Eosinophils $\left(\times 10^{9} / \mathrm{L}\right)$ & $0.32 \pm 0.08$ & $0.32 \pm 0.05$ & $0.35 \pm 0.04$ & $0.32 \pm 0.02$ \\
\hline
\end{tabular}

Values a reexpressed as means \pm SEM. Groups $(n=6)$ : control (treated with Tween 80 ); treatments (treated with $50 \mathrm{mg} / \mathrm{kg}$ MEMM, $250 \mathrm{mg} / \mathrm{kg}$ MEMM, and 1000 mg/kg MEMM)

TABLE 5: Biochemical profiles of liver of Sprague-Dawley rats following the 28-day oral pretreatment with vehicle (Tween 80) or MEMM in the subacute toxicity study.

\begin{tabular}{|c|c|c|c|c|c|c|}
\hline \multirow{4}{*}{ Serum liver parameters } & \multicolumn{3}{|c|}{ Male } & \multicolumn{3}{|c|}{ Female } \\
\hline & \multirow{3}{*}{$\begin{array}{c}\text { Control } \\
\text { Tween } 80 \\
-\end{array}$} & \multirow{2}{*}{\multicolumn{2}{|c|}{$\begin{array}{c}\text { Treatment } \\
\text { MEMM (mg/kg) }\end{array}$}} & \multirow{3}{*}{$\begin{array}{c}\text { Control } \\
\text { Tween } 80 \\
-\end{array}$} & \multirow{2}{*}{\multicolumn{2}{|c|}{$\begin{array}{c}\text { Treatment } \\
\text { MEMM (mg/kg) }\end{array}$}} \\
\hline & & & & & & \\
\hline & & 500 & 1000 & & 500 & 1000 \\
\hline$\overline{A L T}(\mathrm{U} / \mathrm{L})$ & $83.44 \pm 21.06$ & $107.80 \pm 33.25$ & $138.10 \pm 33.18$ & $90.71 \pm 10.18$ & $240.60 \pm 77.36$ & $94.18 \pm 31.23$ \\
\hline ALP (U/L) & $154.80 \pm 23.57$ & $153.80 \pm 22.98$ & $98.60 \pm 9.42$ & $122.26 \pm 14.35$ & $103.80 \pm 8.02$ & $115.80 \pm 12.48$ \\
\hline AST $(\mathrm{U} / \mathrm{L})$ & $352.40 \pm 78.28$ & $342.30 \pm 65.90$ & $227.73 \pm 55.90$ & $381.77 \pm 48.37$ & $332.04 \pm 36.80$ & $344.71 \pm 38.70$ \\
\hline TBil $(\mu \mathrm{mol} / \mathrm{L})$ & $0.80 \pm 0.08$ & $0.62 \pm 0.09$ & $0.76 \pm 0.04$ & $0.41 \pm 0.07$ & $0.28 \pm 0.07$ & $0.24 \pm 0.09$ \\
\hline Creatinine $(\mu \mathrm{mol} / \mathrm{L})$ & $33.60 \pm 1.36$ & $41.40 \pm 8.79$ & $38.40 \pm 6.56$ & $36.57 \pm 8.21$ & $47.00 \pm 8.01$ & $32.40 \pm 5.79$ \\
\hline Urea $(\mathrm{mmol} / \mathrm{L})$ & $8.64 \pm 0.58$ & $10.73 \pm 0.67$ & $10.83 \pm 0.60$ & $9.52 \pm 0.94$ & $11.95 \pm 0.19$ & $6.97 \pm 0.87$ \\
\hline
\end{tabular}

Values are expressed as means \pm SEM. Groups $(n=6)$ : control (treated with Tween 80 ); treatments (treated with $500 \mathrm{mg} / \mathrm{kg} \mathrm{MEMM}$ and $1000 \mathrm{mg} / \mathrm{kg}$ MEMM).

TABLE 6: Biochemical profiles of liver of Sprague-Dawley rats following the 90-day oral pretreatment with vehicle (Tween 80) or MEMM in the subchronic toxicity study.

\begin{tabular}{lcccc}
\hline & & & Male & \multicolumn{2}{c}{ Treatment } \\
Serum liver parameters & Control & & MEMM $(\mathrm{mg} / \mathrm{kg})$ & \\
& Tween 80 & 50 & 500 & 1000 \\
\hline ALT $(\mathrm{U} / \mathrm{L})$ & - & $57.65 \pm 10.89$ & $224.80 \pm 37.52^{*}$ & $236.50 \pm 16.83^{*}$ \\
ALP $(\mathrm{U} / \mathrm{L})$ & $52.58 \pm 4.62$ & $151.50 \pm 15.88$ & $224.10 \pm 49.70$ & $223.60 \pm 45.40$ \\
AST $(\mathrm{U} / \mathrm{L})$ & $136.80 \pm 25.87$ & $235.60 \pm 48.06$ & $1.43 \pm 0.13$ & $1.47 \pm 0.18$ \\
TBil $(\mu \mathrm{mol} / \mathrm{L})$ & $170.30 \pm 16.42$ & $1.36 \pm 0.25$ & $54.75 \pm 1.80$ & $58.50 \pm 2.50$ \\
Creatinine $(\mu \mathrm{mol} / \mathrm{L})$ & $1.58 \pm 0.31$ & $57.75 \pm 2.60$ & $5.43 \pm 0.30$ & $5.75 \pm 0.30$ \\
Urea $(\mathrm{mmol} / \mathrm{L})$ & $61.00 \pm 2.12$ & $7.33 \pm 1.07$ & & \\
\hline
\end{tabular}

Values are expressed as means \pm SEM. Significant different as compared to control, $p<0.05$. Groups $(n=6)$ : control (treated with Tween 80 ); treatments (treated with $50 \mathrm{mg} / \mathrm{kg}$ MEMM, $250 \mathrm{mg} / \mathrm{kg}$ MEMM, and $1000 \mathrm{mg} / \mathrm{kg}$ MEMM)

fragmentation pattern in the negative ion mode) of the peaks detected with those of the compounds detected in the literature or database. Identification of bioactive compounds was confirmed using standard compounds whenever obtainable in-house. The chromatogram profile of MEMM was obtained at three different wavelengths (250, 320, and $360 \mathrm{~nm}$ ) (Figure 3(a)). Figure 3(b) shows some of the phytoconstituents identified in MEMM, which include gallocatechin, quercetin-3,4-diglucoside, quercetin, $p$-coumaric acid, procyanidin $\mathrm{A}$, and epigallocatechin.

\section{Discussion}

For centuries, plant-based natural products have been used throughout the world in the treatment of various disorders. In an attempt to screen for any pharmacological potential, 

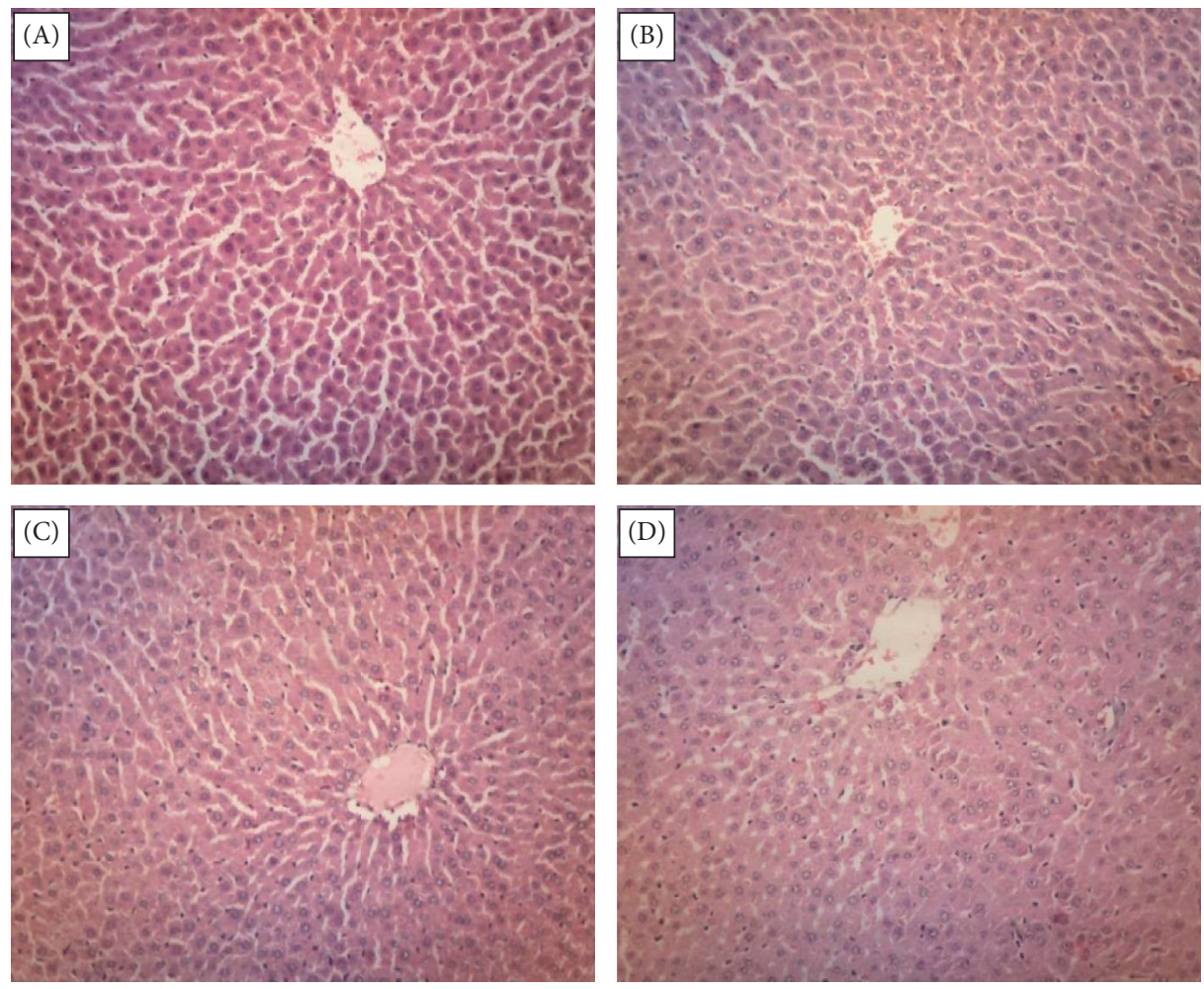

(a)
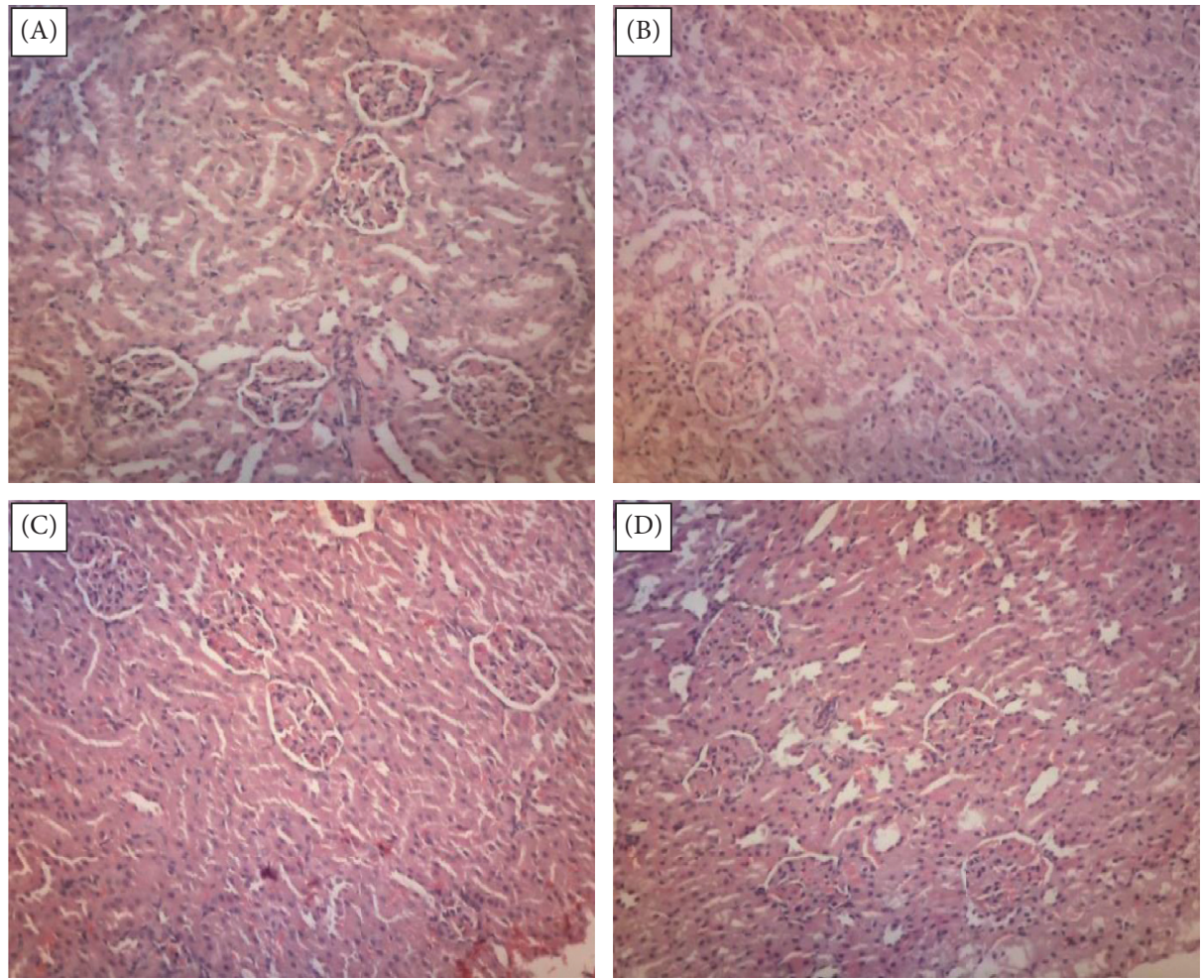

(b)

FIGURE 1: (a) Micrographs of liver section showing normal architecture following treatment with (A) Tween 80 (normal control), (B) 50 mg/ $\mathrm{kg}$ MEMM, (C) $250 \mathrm{mg} / \mathrm{kg}$ MEMM, and (D) $500 \mathrm{mg} / \mathrm{kg}$ MEMM (H\&E, 400x). (b) Micrographs of kidney section showing normal architecture following treatment with (A) Tween 80 (normal control), (B) $50 \mathrm{mg} / \mathrm{kg}$ of MEMM, (C) $250 \mathrm{mg} / \mathrm{kg}$ of MEMM, and (D) $500 \mathrm{mg} / \mathrm{kg}$ of MEMM (H\&E 400x). 

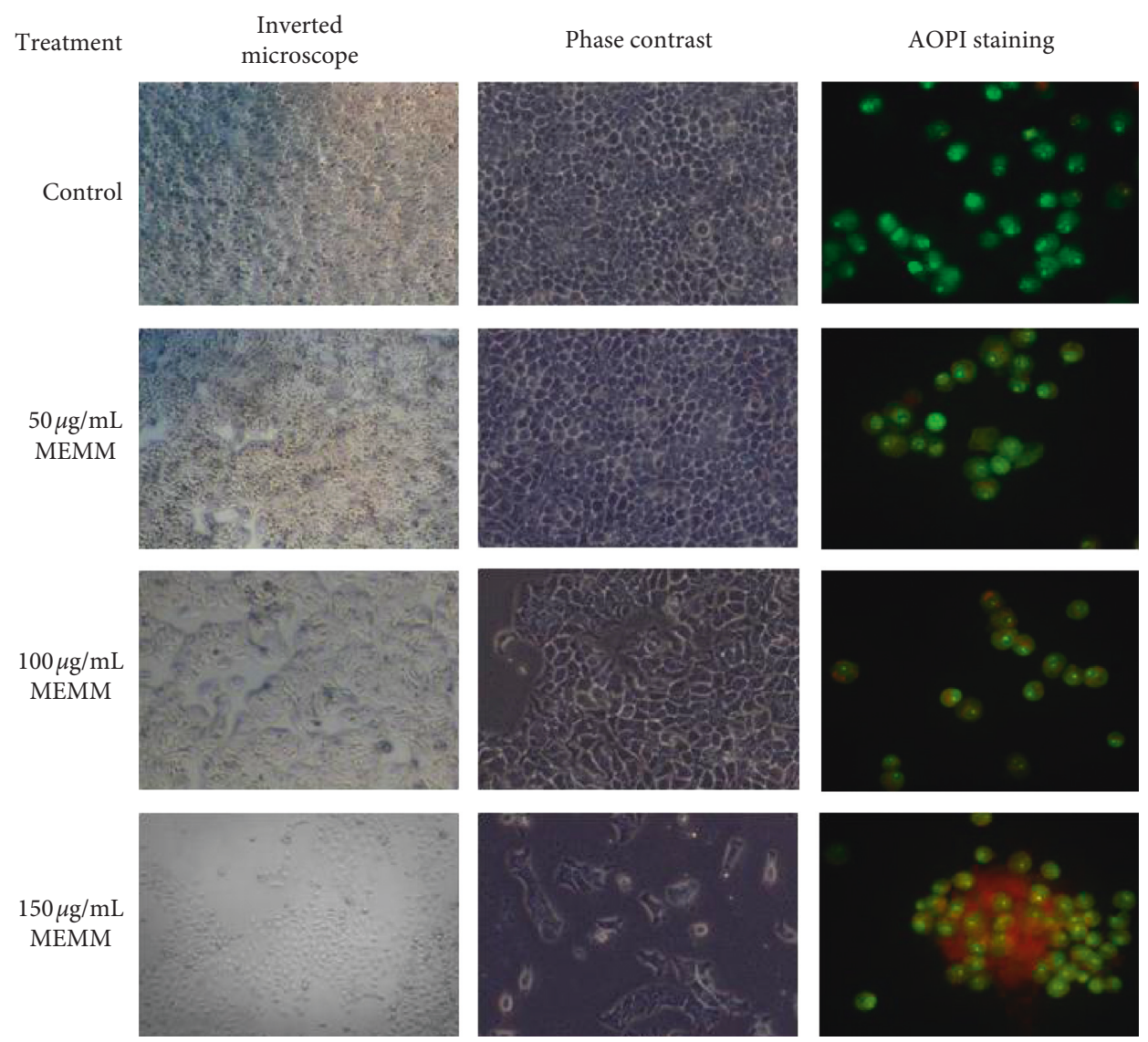

FIGURE 2: Images showing the effect of MEMM at the concentration of 50,100, and $150 \mu \mathrm{g} / \mathrm{mL}$ on human colon cancer cell line (HT29) captured from inverted microscope, phase contrast, and AOPI staining after $72 \mathrm{~h}$.

TABLE 7: Quantitative approach of MEMM and AQMM towards human colon cancer cell line (HT29) once incubated at different concentrations after $72 \mathrm{~h}$.

\begin{tabular}{lccc}
\hline \multirow{2}{*}{ Cells } & \multicolumn{3}{c}{ MEMM (mg/mL) } \\
& 50 & 100 & 150 \\
\hline Viable (\%) & 36 & 26 & 6 \\
Apoptotic (\%) & 50 & 59 & 72 \\
Necrotic (\%) & 14 & 16 & 22 \\
\hline
\end{tabular}

these natural products either in the form of extract, fraction, or compound is usually subjected to the initial evaluation on their toxic characteristics. Despite the presence of various reports on pharmacological potentials of $M$. malabathricum as cited by Mohd. Joffry et al. [4], no thorough knowledge concerning the chronic toxicology of this well-known herb has been published. It is also worth mentioning that the traditional use of any medicinal plant does not guarantee the safety of such a plant for prolonged consumption. Thus, there is a need to obtain data from various models of toxicity studies such as the acute, subacute, subchronic, and, if possible, chronic toxicity on any medicinal plant so as to raise the certainty in its safety to humans especially when the plant has been considered to be developed as pharmaceutical products [17]. To achieve this, it is a crucial step to decide on suitable tests and dosage procedures that will show a sufficient margin of exposure in establishing human safety. Previously, MEMM has been reported to be safe when assessed using the acute toxicity assay. Using the OECD Test Guideline No. 420, the extract, at $5000 \mathrm{mg} / \mathrm{kg}$, was found to cause no sign of toxicity on the tested rats following the 14 days of observation suggesting that the extract has a lethal dose $\left(\mathrm{LD}_{50}\right)$ value greater than $5000 \mathrm{mg} / \mathrm{kg}$ and that no further acute testing should be conducted [18]. In addition, Roopashree et al. [19] stated that the limit test method should not be used primarily as a means to determine the exact $\mathrm{LD}_{50}$ value, but it should be a means to classify the crude plant extract as being safe or nontoxic depending on the expectation at which dose level the animals are anticipated to survive. Based on the OECD recommendation on chemical labeling and classification of acute systemic toxicity, MEMM can be consigned a class 5 status $\left(\mathrm{LD}_{50}>5000 \mathrm{mg} / \mathrm{kg}\right)$, which refers to the lowest toxicity class. In line with this recommendation, Erhirhie et al. [20] also stated that orally administered compounds with $\mathrm{LD}_{50}>5000 \mathrm{mg} / \mathrm{kg}$ are considered to be safe or essentially nontoxic.

Since MEMM did not show any sign of toxic effects in the acute toxicity study, additional assessment needs to be carried out to evaluate the subacute (28-day consumption) and subchronic (90-day consumption) toxicities of MEMM in rats to establish the complete toxicity data of MEMM. 

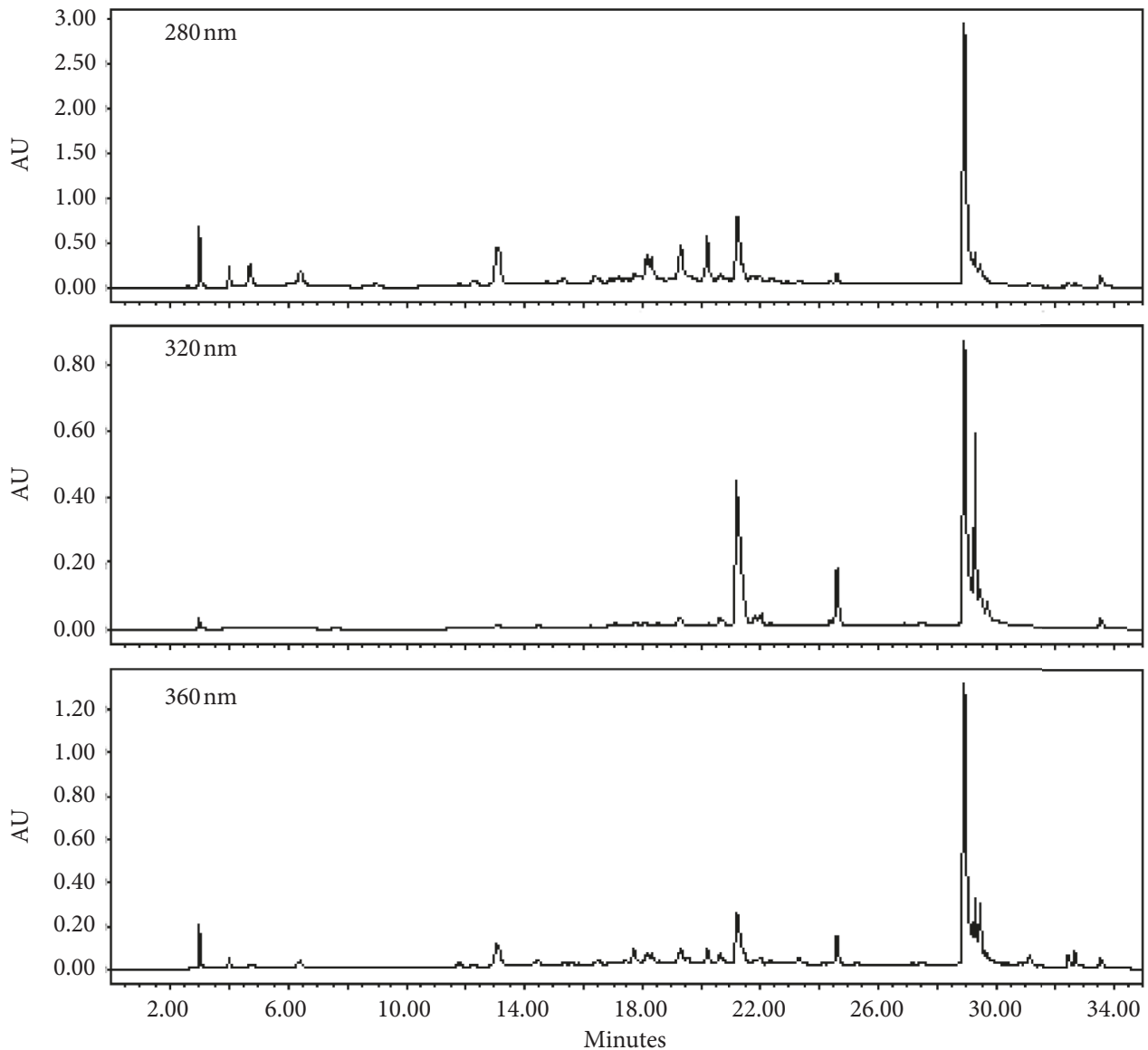

(a)

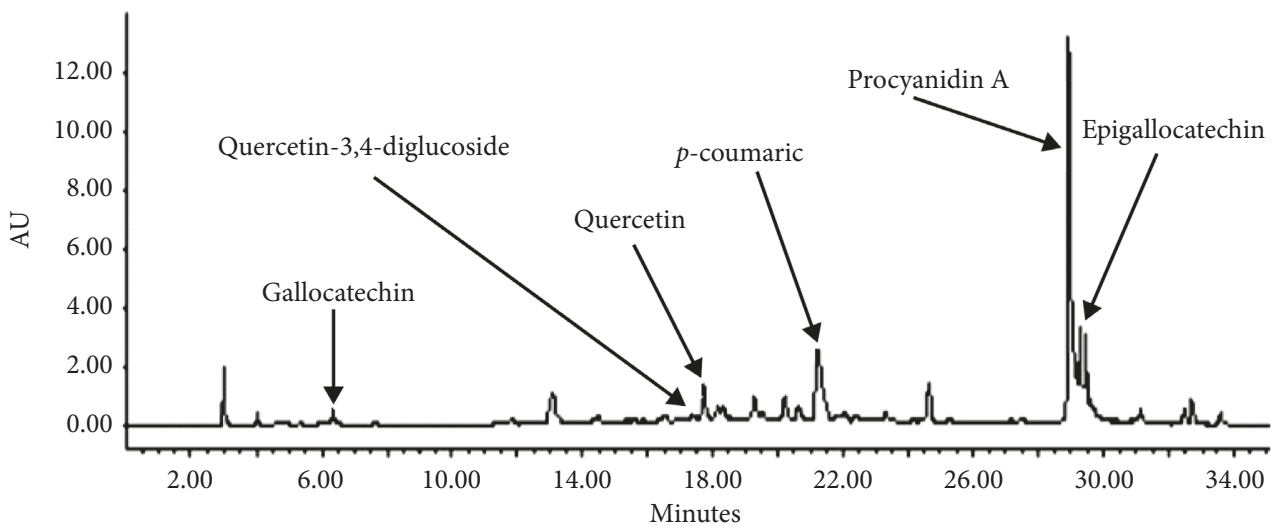

(b)

FIGURE 3: (a) UHPLC-ESI profile of MEMM at various wavelengths (280, 320, and $360 \mathrm{~nm})$. (b) Identification of phytoconstituents of MEMM using the UHPLC-ESI analysis at $360 \mathrm{~nm}$.

Toxicological assessments after repeated exposures are required by regulatory agencies to distinguish the toxicological profile of any substance [10].

Subacute and subchronic investigations measure the unwanted effects of frequent or constant exposure of compounds/extracts over a fraction of the average life period of experimental animals, such as rats. Several objectives could be achieved through these studies such as (i) exclusive information on target organ toxicity, (ii) discovery of no observable adverse effect level, and (iii) determination of appropriate dose regimens for longer-term studies [18]. Subsequently, there is inadequate toxicological information in the literature to support and ensure M. malabatricum safe use, which triggered the present study with the hope of establishing the subacute and subchronic toxicity profiles of MEMM. To the best of our knowledge, this study reported for the first time on the absence of subacute and subchronic toxicity of MEMM in adult rats. 
A considerable decline in food and water intake, which indicates loss of appetite, will lead to a decrease in body weight due to interruptions in the metabolisms of carbohydrate, protein, or fat [21]. Interestingly, the food and water intake was not altered in the group receiving MEMM throughout the 28- or 90-day treatment periods in comparison to the control group, indicating that the extract failed to induce any changes in the metabolisms of carbohydrate, protein, or fat in those rats. Moreover, Yuet Ping [22] also stated that any extract, at higher doses, can be metabolized to a toxic end-product that might hinder the gastric role and decreased food conversion competency. Interestingly, this study also revealed that MEMM did not interfere with the weight gain and appetite stability as seen in the control group that is constantly provided with food and water ad libitum.

Several advantages can be drawn from the findings related to the weighed organs in toxicity studies, which includes (i) the organs sensitivity to acute injury, predict toxicity, physiologic perturbations, and enzyme induction, (ii) the organs are regularly used as target organs of toxicity, (iii) the toxicity effects associate well with histopathological changes, (iv) there is a slight interanimal changeability, and (v) historical control range data are available [23]. Moreover, Mirza and Pancha [24] claimed that the relative organ weights usually measured in toxicity investigations are comparatively sensitive markers for the specific organs and, subsequently, characterize toxicity as substantial changes detected in the particular organs. The outcomes of the present study demonstrated that these essential organs were neither negatively affected nor exerted clinical signs for toxicity throughout the treatment. Thus, it is concluded that MEMM is nontoxic to the analysed organs. Macroscopic observations also further supported the above conclusion as pretreatment with MEMM did not cause changes in colour or presence of hypertrophy on the harvested organs. Hypertrophy of organs is an immediate sign of toxicity following the exposure to a biological or chemical substance. Microscopically, all organs that received MEMM showed no changes in the architecture of cells with any pathologies documented during the histological analysis when viewed under the light microscope.

Estimation of haematological parameters can be utilized to verify the level of detrimental outcomes of compounds/ extracts on the blood of tested animals. In addition, such investigation is pertinent to risk assessment as alterations in the haematological parameters have significant prognostic importance for human toxicity when the data are interpreted from animal studies [25]. Following the haematological analysis, MEMM was found to cause no significant changes in the level of several parameters measured. A normal haematological profile observed in MEMM-treated groups when compared to the control group further justified the nontoxic nature of MEMM [26].

Another important indicator of toxicity can be obtained by studying the liver following the administration of test substance. According to Zhang et al. [27], it is important to perform the liver and kidney function analyses during the toxicity assessment of compounds/extracts as data from both analyses are essential for determining the survival of an organism. The estimation of any substance level in the blood can help to facilitate in the early detection of liver injury. Other than the blood parameters, some biochemical markers (i.e., ALT, AST, and ALP) and total bilirubin (TBil) can be used to diagnose a liver injury. A number of enzymes, produced and generally found in the hepatocytes cells of the liver, are involved in the modulation of various chemical reactions in the body. Nevertheless, if the liver is injured or harmed, these enzymes will leak into the blood circulation resulting in the rise of liver enzymes' level, which can be considered as a significant sign of liver toxicity. Meanwhile, a rise in both the total and conjugated bilirubin levels could be used as a measure to determine the overall liver function. An increase in the levels of ALT or AST in combination with an increase to more than double the normal upper level of bilirubin is regarded as a warning sign for hepatotoxicity [28]. Principally, acute or chronic injury to the liver will eventually result in an increase in serum concentrations of AST and ALT. ALT, which is found mainly in the liver, has always been the most commonly relied biomarker of hepatotoxicity and its estimation is considered as a more specific test for detecting liver malfunctions and might indicate hepatocellular necrosis. On the contrary, AST, which is found in the liver as well as in the other organs (i.e., heart, brain, muscle, and kidney) and also assists in spotting hepatocellular necrosis, is regarded as a non-specific biomarker enzyme for liver injury since its serum level elevation can also indicate malfunctions in those other organs. The levels of ALT and AST or together with TBil in rodents and nonrodents are mostly commended for the evaluation of hepatocellular injury in nonclinical investigations. Furthermore, histopathological observations also allow confirmation of hepatotoxicity. With regard to renal dysfunction, concurrent determination on the level of urea, creatinine, and uric acid could be performed and if their normal levels were detected, it is conceivable to suggest the absence of renal problems [29]. In this study, the levels of urea, creatinine, and uric acid in MEMM-treated groups did not differ significantly in comparison to the control group, indicating a normal renal function. Bilirubin, which is an endogenous anion normally present in the blood in small quantities as a result of the normal degradation of haemoglobin, is removed from the liver via the bile system. However, injury to the hepatocytes results in the liver inability to excrete bilirubin in the usual manner, thus increasing the level of bilirubin in the blood and extracellular fluid. Due to this, bilirubin is also classified as a biomarker of hepatobiliary injury and often measured together during the hepatoprotective study. However, in the present study, MEMM was found to cause no change in ALT, AST, and TBil levels. These observations indicated that MEMM did not cause liver damage following the oral administration. With regard to the kidney function, there were also insignificant changes in urea, creatinine, and uric acid levels following the subchronic oral administration of MEMM into rats when compared to the control group. This statement is also concurrent with the present histopathological findings of the kidney tissue, which showed normal architecture, as 
seen in the control group. Thus, the liver and renal function data supported by their histological findings suggest the nontoxic nature of MEMM.

Although the level of ALP is not considered important in the determination of liver injury, the significant level of ALP detected in the present subchronic study need to be discussed. ALP, which is predominantly found in the cells that line the biliary ducts of the liver, is also found in other organs (i.e., bone, placenta, kidney, and intestine) and removed in the bile. Its serum level may be raised of the normal value if bile excretion is hindered by liver injury due to the congestion or obstruction of the biliary tract (also known as cholestasis). Other than that, the level of ALP, an enzyme that transports metabolites across cell membranes, can also be elevated due to the presence of liver and bone diseases despite the fact that ALP may originate from other tissues, such as the placenta, kidneys, or intestines or from leukocytes [30]. In the present study, there was a significant increase in the level of ALP following pretreatment with MEMM, which was not accompanied by increase in ALT and AST levels, suggesting that the increase in ALP level was not associated primarily with hepatocellular injury [31]. Although cholestasis enhances the synthesis and release of ALP and accumulating bile salts increase its release from the cell surface, their presence can be ruled out as the microscopic examination demonstrated the normal architecture of the liver tissue at all doses of MEMM tested. Several reports have demonstrated the ability of plants' extracts to affect the level of ALP either at the tissue (i.e., liver) or serum level $[32,33]$. According to the report by Omage et al. [32], the oral administration of aqueous or ethanol extracts of Acalypha wilkesiana leaves significantly changed the level of serum ALP, ALT, and AST when measured at different day intervals $(0,7,14$, and 21 days). Based on their reports, the aqueous extract caused significant reduction in the serum ALP level at day 7 and day 21, whereas the ethanol extract caused significant increase in the serum ALT level only at day 14. As for the serum AST level, the aqueous extract caused significant reduction in the AST level at day 7 and day 21 with significant increase in the AST level seen only at day 14. In comparison, the ethanol extract caused reduction in the serum level of AST at all intervals measured with the significant reduction observed only at day 21 . With regard to the serum ALP level, the aqueous extract caused significant increase in the ALP level at day 7 and day 21, while for the ethanol extract, significant increase in the level of serum ALP was observed only at day 21 . In comparison to the report made by Omage et al. [32], MEMM did not significantly change or affect the levels of serum ALT and AST, thus suggesting that the increase in the serum ALP level did not directly relate to the MEMM ability to induce liver injury following the oral administration. On the contrary, Yakubu et al. [33] reported on the ability of ethanolic extract of Khaya senegalensis stem bark to increase the levels of liver tissue ALP without affecting the level of serum ALP when measured at day 6 and day 18 in comparison to the control group, and these findings were also observed for the liver tissue and serum levels of AST. However, the liver tissue level of ALT, which was decreased at day 6 and increased at day 18 , was also accompanied by the increased in the serum ALT level at day 6, but not day 18. According to Yakubu et al. [33], the significant increase in the liver ALP activity following the administration of the plant extract may be due to increased functional activity of the liver, probably leading to de novo synthesis of the enzyme molecules. Such excess level of serum ALP, which was accompanied by no concomitant increase in the serum level of ALT, AST, as well a TBil, may suggest that the integrity of the liver plasma membrane was not compromised following the administration of the plant extract. However, since the ALP hydrolyses phosphate monoesters, which play role in the facilitation of the transfer of metabolites across the cell membrane, the subchronic and chronic use of M. malabathricum leaves need to be carried out with caution. Furthermore, the fact that the effect of MEMM on the serum ALP level was observed only in the subchronic study could also be associated with the ALP's longer half-life, which caused the enzyme serum level to decrease slowly after resolution and make the enzyme stay in the circulation longer in comparison to ALT and AST [34].

Chemotherapy has been successfully used in the treatment of several tumors such as testicular cancer and certain leukaemia's. However, its achievement against common epithelial tumors of the breast, colon, and lung has been less than impressive [35]. Preferably, chemotherapeutic agents should exclusively target just neoplastic cells and should reduce tumor burden by stimulating cytotoxic effects without injuring the normal cells. However, the efficacy of chemotherapy has experienced a variety of confounding factors including systemic toxicity, which is attributable to the unspecific action, instantaneous metabolism of drug, and both intrinsic and acquired drug resistance [30]. Due to these factors and worsened by other issues such as ineffective therapeutic strategies to control and treat colon cancer, the high financial burden incurred on the patients and their families as well as the nations have demanded the look for novel remedies largely from the natural product sources [36]. This might explain the increase in awareness in the usage of natural products as an alternative approach to effectively control cancers in recent years [37].

One of the most important methods for evaluating anticancer properties of any extract/compound is the cytotoxicity test, which uses cancer cells in vitro to watch the cancer cell growth, reproduction, and morphological effects upon exposure to the extract/compound [38]. Cytotoxicity has a series of advantages such as it is modest, precipitous, highly sensitive, and can protect the animals from toxicity [38]. With the constant progress in cytotoxicity testing, various procedures, including discovery of cell injury by observing the cells' morphological changes, determining the mode of cells damage, quantifying the cells' growth and metabolic properties, have emerged and had progressively been expanded from qualitative approaches to quantitative evaluations [39].

One of the mechanisms of anticancer is apoptosis, which is a very organized physiological machinery to abolish damaged or abnormal cells [40]. Apoptosis, which is a programmed cell death, is a smart screening endpoint in the discovery and development of novel anticancer drugs. An 
extensive range of natural substances present in plants has been documented to possess the capacity to cause apoptosis in numerous tumor cells of human origin [41, 42]. MEMM possessed high content of phenolic compounds [8] and exerts many pharmacological and biological activities including antioxidative [8], anti-inflammatory [43], and antiproliferative activities [44]. Various bioactive compounds have been isolated from MEMM, such as ursolic acid, 2-hydroxyursolic acid, asiatic acid, gallic acid, $p$ hydroxybenzoic acid, kaempferol, kaempferol-3-O-(2",6" di-O-p-trans-coumaroyl)- $\beta$-glucoside, $\alpha$-amyrin, uvaol, quercetin, quercitrin, and rutin [4]. Of these, ursolic acid [45], asiatic acid [46], kaempferol [47], quercetin [48], and rutin [49] have been reported to exert anticolon cancer activity against the HT29 cancer cell line. In the recent report, MEMM was analysed using the UHPLC-ESI procedure and revealed the presence of caffeic acid, chlorogenic acid, $p$-coumaric acid, gallocatechin, epigallocatechin, catechin, quercetin, quercetin-3-O-glucoside, and hesperidin [50]. Of these, caffeic acid [51], quercetin, and p-coumaric [52] have been reported to exert anticolon cancer activity against the HT29 cancer cell line. Thus, it is reasonable to propose that the observed anticolon cancer activity of MEMM involves, in part, the synergistic action of those bioactive compounds.

\section{Conclusion}

In conclusion, $M$. malabathricum leaves, in the form of MEMM, did not exert any signs of toxic effects on rats with regard to their behaviour, body weight, haematological and biochemical parameters, and relative organs weight following the subacute (28 days) or subchronic (90 days) oral administration of the extract. Hence, no observed adverse-effect level (NOAEL) was detected, and NOAEL for this extract has been determined to be greater than $500 \mathrm{mg} / \mathrm{kg}$. MEMM also showed cytotoxic activity against the HT29 colon cancer cells partly via apoptosis and possibly through the synergistic action of several flavonoids presence in the extract.

\section{Abbreviations}

MEMM: Methanol extract of Melastoma malabathricum

OECD: Organisation for Economic Co-operation and Development

MTT: 3-(4,5-Dimethylthiazol-2-yl)-2,5diphenyltetrazolium bromide

ALP: $\quad$ Alkaline phosphatase

UPM: Universiti Putra Malaysia

IBS: Institute of Bioscience

IACUC: Institute Animal Care and Use Committee

RBC: $\quad$ Red blood count

$\mathrm{Hb}$ : Haemoglobin

MCHC: Mean corpuscular haemoglobin concentration

MCV: Mean corpuscular volume

PCV: $\quad$ Packed cell volume

WBC: White blood cell

ALT: Alanine aminotransferase

AST: Aspartate aminotransferase
Crea: Creatinine

TBil: Total bilirubin

ATCC: American Type Culture Collection

RPMI: Roswell Park Memorial Institute 1640

FBS: $\quad$ Fetal bovine serum

Pen- Penicillin-streptomycin

Strep:

$\mathrm{CO}_{2}$ : $\quad$ Carbon dioxide

DMSO: Dimethyl sulfoxide

PBS: $\quad$ Phosphate buffer saline

AO: Acridine orange

PI: $\quad$ Propidium iodide

ANOVA: Analysis of Variance

LD: $\quad$ Lethal dose

NOAEL: Observed-adverse-effect level.

\section{Data Availability}

The supporting materials can be obtained upon request via email to the corresponding author.

\section{Ethical Approval}

The study protocol involving the use of animals in the present study was approved by the Institutional Animal Care and Use Committee (IACUC), Faculty of Veterinary Medicine, Universiti Putra Malaysia (IACUC no: UPM/ IACUC/AUP-R007/2014).

\section{Conflicts of Interest}

The authors declare that there are no conflicts of interest.

\section{Authors' Contributions}

NEK, NLMN, and SSM carried out the animal toxicity studies and performed the macroscopic and microscopic analyses. NB involved in the cytotoxic study. NM was involved in the macroscopic and microscopic analysis. MT participated in the design of study and helped with the statistical analysis. ZAZ conceived the study, participated in its design, and helped to draft the manuscript. All authors read and approved the final manuscript.

\section{Acknowledgments}

The authors thanked the Faculty of Medicine and Health Sciences, UPM, Malaysia, for providing the facilities and supporting this study. This research was supported by the Fundamental Research Grant Scheme (FRGS; Reference no.: 04-01-14-1445FR) and Transdisciplinary Research Grant Scheme (TRGS; Reference no: 600-RM|/TRGS 5/3 (112014)), which were awarded by the Ministry of Higher Education (MOHE), Malaysia.

\section{References}

[1] D. Begum and S. C. Nath, "Ethnobotanical review of medicinal plants used for skin diseases and related problems in 
Northeastern India," Journal of Herbs, Spices and Medicinal Plants, vol. 7, no. 3, pp. 55-93, 2000.

[2] S. Bharadwaj and S. K. Gakhar, "Ethnomedicinal plants used by tribals of Mizorum to use cuts and wounds," Indian Journal of Traditional Knowledge, vol. 4, pp. 75-80, 2005.

[3] S. S. Koay, Establishment of cell suspension culture of Melastoma malabathricum L. for the production of anthocyanin, Ph.D. thesis, Universiti Sains Malaysia, Pulau Pinang, Malaysia, 2008.

[4] S. M. Joffry, N. J. Yob, M. S. Rofiee et al., "Melastoma malabathricum(L.) smith ethnomedicinal uses, chemical constituents, and pharmacological properties: a review," Evidence-Based Complementary and Alternative Medicine, vol. 2012, pp. 1-48, 2012.

[5] E. S. Jaios, S. Abdul Rahman, S. M. Ching et al., "Mechanisms of antinociceptive activity exerted by orally administered methanol extract of Melastoma malabathricum leaves," Brazilian Journal of Pharmacognosy, vol. 201, no. 26, pp. 586-594.

[6] F. Lohézic-Le Dévéhat, A. Bakhtiar, C. Bézivin, M. Amoros, J. Boustie et al., "Antiviral and cytotoxic activities of some Indonesian plants," Fitoterapia, vol. 73, no. 5, pp. 400-405, 2002.

[7] I. Nazlina, S. Norha, A. W. Noor Zarina, and I. B. Ahmad, "Cytotoxicity and antiviral activity of Melastoma malabathricum extracts," Malaysian Applied Biology Journal, vol. 37, pp. 53-55, 2008.

[8] S. S. Mamat, M. F. F. Kamarolzaman, F. Yahya et al., "Methanol extract of Melastoma malabathricum leaves exerted antioxidant and liver protective activity in rats," $B M C$ Complementary and Alternative Medicine, vol. 13, no. 1, p. 326, 2013.

[9] S. A. A. Ghafar, L. S. Yazan, P. M. Tahir, and M. Ismail, "Kenaf seed supercritical fluid extract reduces aberrant crypt foci formation in azoxymethane-induced rats," Experimental and Toxicologic Pathology, vol. 64, no. 3, pp. 247-251, 2012.

[10] OECD 2008, OECD Guidelines for the Testing of Chemicals (Section 4), Test No. 407: Repeated Dose 28-day Oral Toxicity Study in Rodents, OECD, Paris, France, 2008.

[11] OECD 1998, OECD Guidelines for the Testing of Chemicals (Section 4), Test No. 408: Repeated Dose 90-day Oral Toxicity Study in Rodents, OECD, Paris, France, 1998.

[12] M. B. Adinortey, C. Ansah, I. Galyuon, and A. Nyarko, "In vivo models used for evaluation of potential antigastroduodenal ulcer agents," Ulcers, vol. 2013, Article ID 796405, 12 pages, 2013.

[13] M. Porwal, N. Ali Khan, and K. K. Maheshwari, "Evaluation of acute and subacute oral toxicity induced by ethanolic extract of Marsdenia tenacissima leaves in experimental rats," Scientia Pharmaceutica, vol. 29, no. 3, p. 85, 2017.

[14] Z. A. Zakaria, A. M. Mohamed, N. S. M. Jamil et al., "In vitro antiproliferative and antioxidant activities of the extracts of Muntingia calabura leaves," The American Journal of Chinese Medicine, vol. 39, no. 1, pp. 183-200, 2011.

[15] S. M. Hussain, K. L. Hess, J. M. Gearhart, K. T. Geiss, J. J. Schlager et al., "In vitro toxicity of nanoparticles in BRL 3A rat liver cells," Toxicology in Vitro, vol. 19, no. 7, pp. 975-983, 2005.

[16] L. B. Harvey, "Rapid assessment of islet viability with acridine orange and propidium iodide," In Vitro Cellular and Developmental Biology, vol. 24, pp. 266-273, 1988.

[17] A. N. Ukwuani, M. G. Abubakar, S. W. Hassan, and B. M. Agaie, "Toxicological studies of hydromethanolic leaves extract of Grewia crenata," International Journal of
Pharmaceutical Sciences and Drug Research, vol. 4, pp. 245249, 2012.

[18] National Research Council, "Toxicity testing for assessing environmental agents," Interim Report, National Academies Press, Washington, DC, USA, 2008.

[19] T. S. Roopashree, D. Raman, R. H. S. Rani, and C. Narendra, "Acute oral toxicity studies of antipsoriatic herbal mixture comprising of aqueous extracts of Calendula officinalis, Momordica charantia, Cassia tora and Azadirachta indica seed oil," Thai Journal of Pharmaceutical Sciences, vol. 33, pp. 74-83, 2009.

[20] E. O. Erhirhie, C. P. Ihekwereme, and E. E. Ilodigwe, "Advances in acute toxicity testing: strengths, weaknesses and regulatory acceptance," Interdisciplinary Toxicology, vol. 11, no. 1, pp. 5-12, 2018.

[21] CD. Klaassen, Casarett and Doull's Toxicology: The Basic Science of Poisons, McGraw-Hill Education, Columbus, OH, USA, 9th edition, 2018.

[22] K. Yuet Ping, I. Darah, Y. Chen, S. Sreeramanan, and S. Sasidharan, "Acute and subchronic toxicity study of Euphorbia hirta L. methanol extract in rats," BioMed Research International, vol. 2013, pp. 1-14, 2013.

[23] R. Nirogi, V. K. Goyal, S. Jana, S. K. Pandey, and A. Gothi, "What suits best for organ weight analysis: review of relationship between organ weight and body/brain weight for rodent toxicity study," International Journal of Pharmaceutical Sciences and Research, vol. 5, pp. 1525-1532, 2014.

[24] A. C. Mirza and S. S. Pancha, "Safety evaluation of syringic acid: subacute oral toxicity studies in Wistar rats," Heliyon, vol. 5, Article ID e02129, 2019.

[25] N. J. Muriithi, G. S. Maina, M. B. Maina et al., "Determination of hematological effects of methanolic leaf extract of vernonia lasiopus in normal mice," Journal of Blood and Lymph, vol. 5, p. 139, 2015.

[26] J. E. Hall, Huyton and Hall Textbook of Medical Physiologyp. 1168, 13th edition, W.B Saunders, PA, USA, 2015.

[27] Y. Zhang, E. Guan, X. Zhao et al., "A subchronic toxicity study of ethanol root extract of baked Aconitum flavum in rats," Revista Brasileira de Farmacognosia, vol. 26, no. 4, pp. 438445, 2016.

[28] P. Sriuttha, B. Sirichanchuen, and U. Permsuwan, "Hepatotoxicity of nonsteroidal anti-inflammatory drugs: a systematic review of randomized controlled trials," International Journal of Hepatology, vol. 2018, Article ID 5253623, 13 pages, 2018.

[29] L. M. A. Barnett and B. S. Cummings, "Nephrotoxicity and renal pathophysiology: a contemporary perspective," Toxicological Sciences, vol. 164, no. 2, pp. 379-390, 2018.

[30] W. H. Fishman, "Alkaline phosphatase isozymes: recent progress," Clinical Biochemistry, vol. 23, no. 2, pp. 99-104, 1990.

[31] D. R. Dufour, J. A. Lott, F. S. Nolte et al., "Diagnosis and monitoring of hepatic injury. I. Performance characteristics of laboratory tests," Clinical Chemistry, vol. 46, pp. 2027-2049, 2000.

[32] K. Omage, M. A. Azeke, J. N. E. Orhue, and S. O. Iseghohi, "Toxicological implications of the therapeutic use of Acalypha wilkesiana leaves in traditional medicine," Clinical Phytoscience, vol. 3, no. 1, 2017.

[33] M. T. Yakubu, O. J. Adebayo, E. C. Egwim, and V. B. Qwoyele, "Increased liver alkaline phosphatase and aminotransferase activities following administration of ethanolic extract of Khaya senegalensis stem bark to rats," Biokemistri, vol. 17, no. 1, pp. 27-32, 2005. 
[34] D. R. Dufour, J. A. Lott, F. S. Nolte et al., "Diagnosis and monitoring of hepatic injury. I. Performance characteristics of laboratory tests," Clinical Chemistry, vol. 46, pp. 2027-2049, 2000.

[35] H. Liu, L. Lv, and K. Yang, "Chemotherapy targeting cancer stem cells," American Journal of Cancer Research, vol. 5, pp. 880-893, 2015.

[36] J. Iqbal, B. A. Abbasi, T. Mahmood et al., "Plant-derived anticancer agents: a green anticancer approach," Asian Pacific Journal of Tropical Biomedicine, vol. 7, no. 12, pp. 1129-1150, 2017.

[37] S. Mitra and R. Dash, "Natural products for the management and prevention of breast cancer," Evidence-Based Complementary and Alternative Medicine, vol. 2018, Article ID 8324696, 23 pages, 2018.

[38] ÖS. Aslantürk, "In vitro cytotoxicity and cell viability assays: principles, advantages, and disadvantages," in Genotoxicity-A Predictable Risk to Our Actual World, M. L. Larramendy and S. Soloneski, Eds., IntechOpen, London, UK, pp. 1-17, 2018.

[39] W. Li, J. Zhou, and Y. Xu, "Study of the in vitro cytotoxicity testing of medical devices," Biomedical Reports, vol. 3, no. 5, pp. 617-620, 2015.

[40] A. Letai, "Apoptosis and cancer," Annual Review of Cancer Biology, vol. 1, no. 1, pp. 275-294, 2017.

[41] C. Kim and B. Kim, "Anti-cancer natural products and their bioactive anti-cancer natural products and their bioactive compounds inducing ER stress-mediated apoptosis: a review," Nutrients, vol. 10, no. 8, p. 1021, 2018.

[42] Y. Wang, J. Zhong, J. Bai et al., "The application of natural products in cancer therapy by targeting apoptosis pathways," Current Drug Metabolism, vol. 19, no. 9, pp. 739-749, 2018.

[43] Z. A. Zakaria, T. Balan, S. S. Mamat, N. Mohtarrudin, L. K. Teh, and M. Z. Salleh, "Mechanisms of gastroprotection of methanol extract of Melastoma malabathricum leaves," BMC Complementary and Alternative Medicine, vol. 15, no. 1, p. 135, 2015.

[44] Z. A. Zakaria, M. S. Rofiee, A. M. Mohamed, L. K. Teh, and M. Z. Salleh, "In vitro antiproliferative and antioxidant activities and total phenolic contents of the extracts of Melastoma malabathricum leaves," Journal of Acupuncture and Meridian Studies, vol. 4, no. 4, pp. 248-256, 2011.

[45] G.-X. Yang, R.-Z. Zhang, B. Lou et al., "Chemical constituents from Melastoma dodec and rum and their inhibitory activity on interleukin-8 production in HT-29 cells," Natural Product Research, vol. 28, no. 17, pp. 1383-1387, 2014.

[46] P. Bunpo, K. Kataoka, H. Arimochi et al., "Inhibitory effects of asiatic acid and CPT-11 on growth of HT-29 cells," The Journal of Medical Investigation, vol. 52, no. 1-2, pp. 65-73, 2005.

[47] H. Lee, H. Cho, R. Yu et al., "Mechanisms underlying apoptosis-inducing effects of kaempferol in HT-29 human colon cancer cells," International Journal of Molecular Sciences, vol. 15, no. 2, pp. 2722-2737, 2014.

[48] L. Yang, Y. Liu, M. Wang et al., "Quercetin-induced apoptosis of HT-29 colon cancer cells via inhibition of the Akt-CSN6Myc signaling axis," Molecular Medicine Reports, vol. 14, no. 5, pp. 4559-4566, 2016.

[49] M. ben Sghaier, A. Pagano, M. Mousslim et al., "Rutin inhibits proliferation, attenuates superoxide production and decreases adhesion and migration of human cancerous cells," Biomedicine and Pharmacotherapy, vol. 84, pp. 1972-1978, 2016.

[50] N. W. Ismail Suhaimy, A. K. Noor Azmi, N. Mohtarrudin et al., "Semi-purified ethyl acetate partition of methanolic extract of Melastoma malabathricum leaves exerts gastroprotective activity partly via its antioxidant-antisecretoryanti-inflammatory action and synergistic action of several flavonoid-based compounds," Oxidative Medicine and Cellular Longevity, vol. 2017, Article ID 6542631, 14 pages, 2017.

[51] S. Hajmohamad Ebrahim Ketabforoosh, M. Amini, M. Vosooghi et al., "Synthesis, evaluation of anticancer activity and QSAR study of heterocyclic esters of caffeic acid," Iranian Journal of Pharmaceutical Research, vol. 12, no. 4, pp. 705-719, 2013.

[52] N. Nasr Bouzaiene, S. Kilani Jaziri, H. Kovacic et al., "The effects of caffeic, coumaric and ferulic acids on proliferation, superoxide production, adhesion and migration of human tumor cells in vitro," European Journal of Pharmacology, vol. 766, pp. 99-105, 2015. 


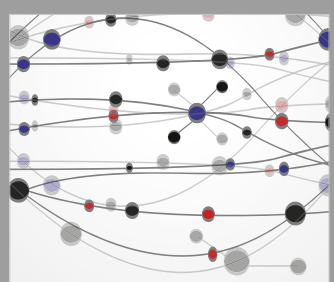

The Scientific World Journal
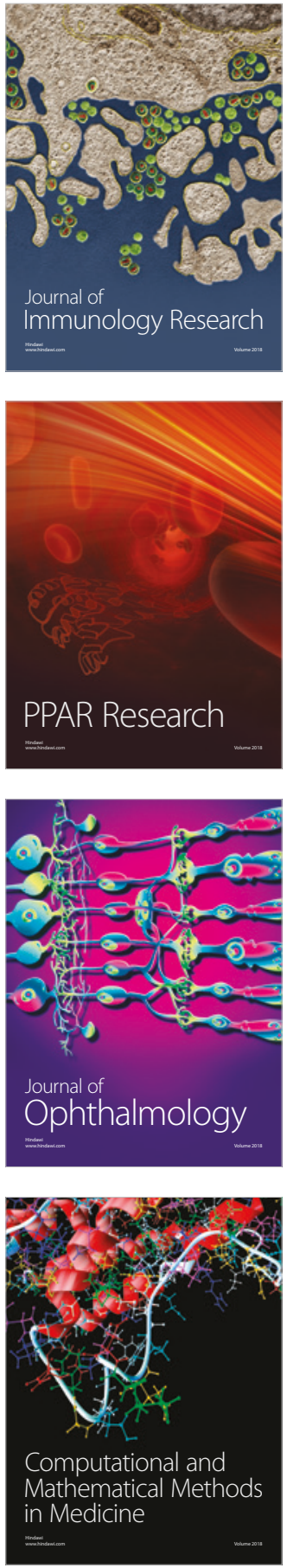

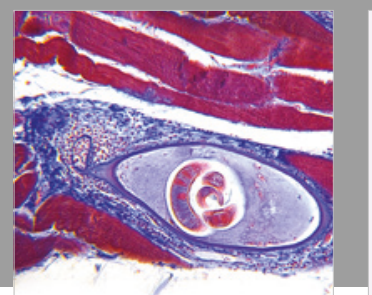

Gastroenterology Research and Practice

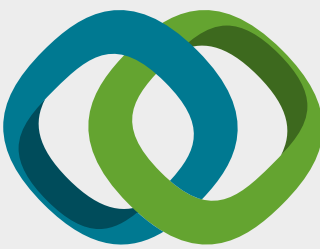

\section{Hindawi}

Submit your manuscripts at

www.hindawi.com
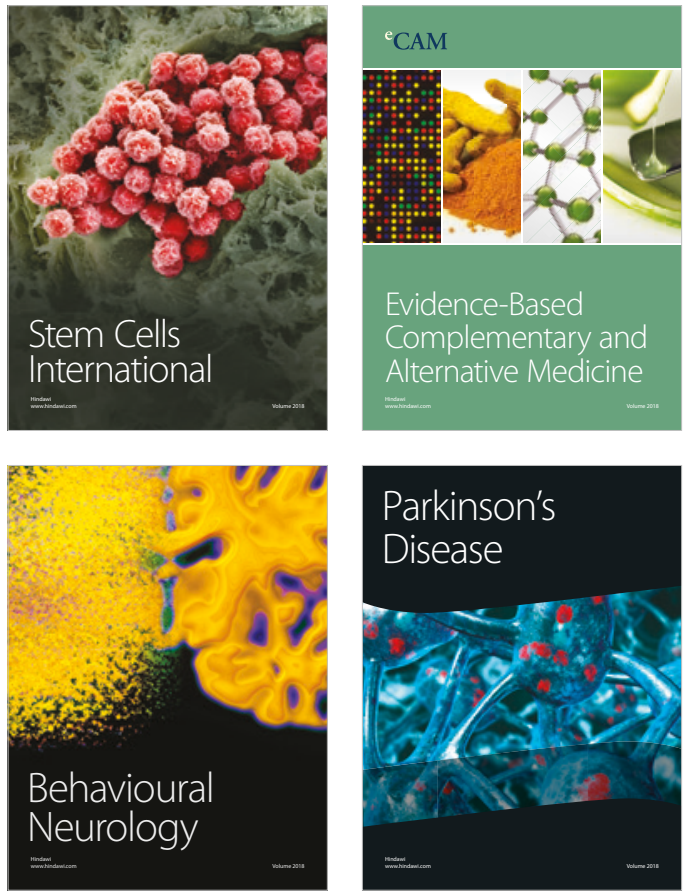

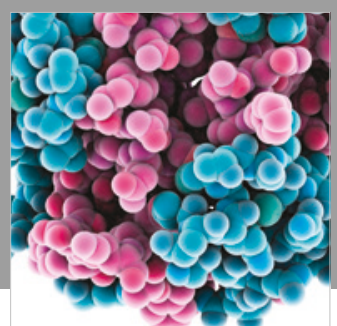

ournal of

Diabetes Research

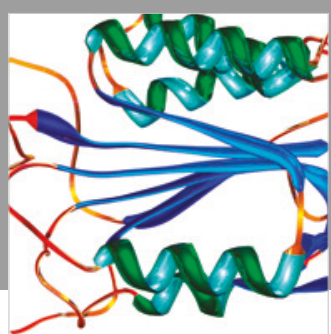

Disease Markers
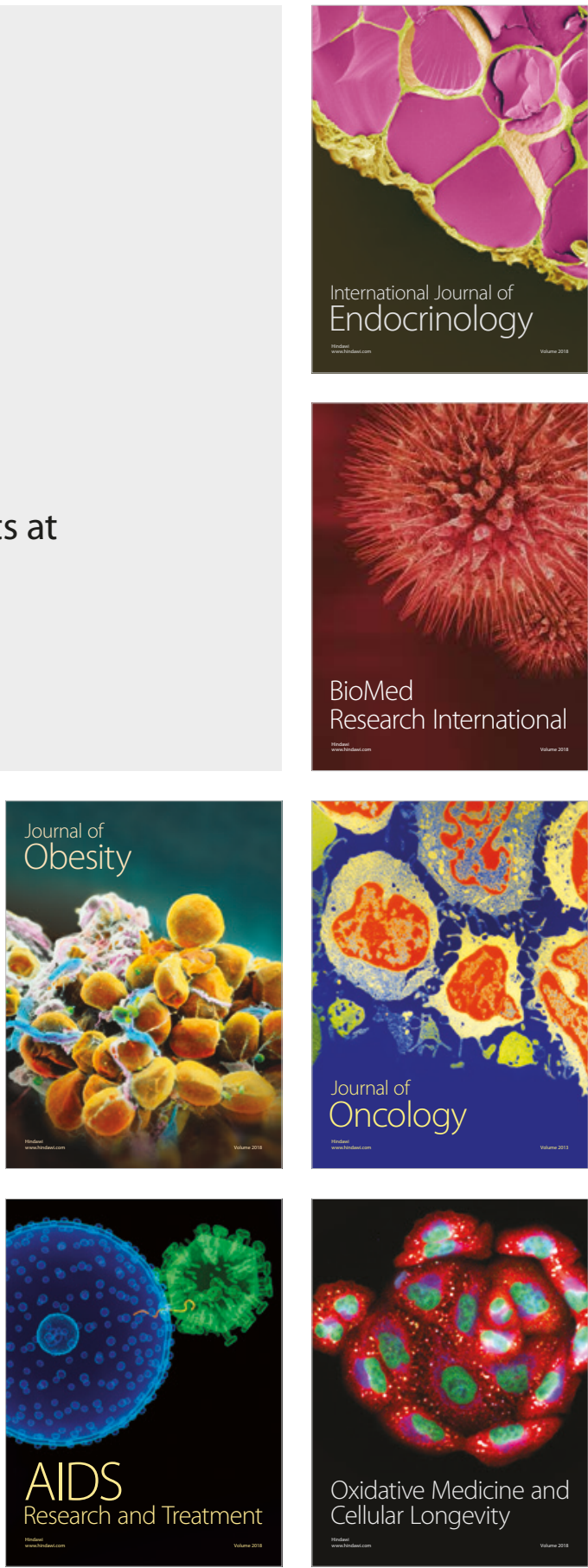